Konrad Michalski

Szkola Glowna Gospodarstwa Wiejskiego w Warszawie

\title{
Megatrendy rozwojowe współczesnej branży pocztowej
}

\author{
DEVELOPMENT MEGATRENDS OF THE \\ CONTEMPORARY POSTAL INDUSTRY
}

\begin{abstract}
Branża pocztowa, której tradycyjnym produktem sq list i paczka, traktowana jest obecnie jako część szerszego rynku KEP (kurier, ekspres, paczka). Dla rynku KEP można zidentyfikować zjawiska rozwojowe (megatrendy) majace wpływ na jego funkcjonowanie $w$ dtuższej perspektywie. Wiedza o tych zjawiskach powinna być podstawq każdej decyzji o strategicznym charakterze.

Celem opracowania jest usystematyzowanie istoty zmian $w$ otoczeniu branży pocztowej. Niektóre zjawiska $w$ otoczeniu tego rynku już przyczynity się do komodyzacji (utraty wartości $i$ konieczności redefinicji podstawowych założeń) niektórych rodzajów ustug, a $w$ odniesieniu do innych, do ich calkowitego zniknięcia z rynku. Megatrendy w otoczeniu branży pocztowej decyduja o tym, że publiczni operatorzy stoja dzisiaj przed koniecznościq zmiany modeli funkcjonowania. Być może, w niedalekiej przyszłości, konieczność zmian będzie dotyczyć także paradygmatów zarzqdzania.

Artykut podejmuje tematykę branży pocztowej z perspektywy wyzwań w zakresie zarzadzania, gdzie zauważyć można istotna lukę $w$ polskim piśmiennictwie. Opracowanie ma charakter teoretyczny $z$ aspektami praktycznymi i jest oparty na przegladzie literatury naukowej oraz popularno-naukowej. W artykule dokonano aktualizacji literatury z punktu widzenia obecnego stanu rzeczy branży pocztowej. Wykorzystano wtórne źródta danych.
\end{abstract}

Slowa kluczowe: megatrendy rozwojowe, KEP, logistyka 4.0, komodyzacja, operator pocztowy.

\section{Wprowadzenie}

Do najistotniejszych trendów, które od lat 90 . XX w., były obserwowane w otoczeniu operatorów pocztowych w UE (ówcześnie, były nimi przede wszystkim poczty narodowe poszczególnych krajów), należy zaliczyć globalizację. Powiązana $\mathrm{z}$ liberalizacją rynków unijnych zmiana roli państwa i ich instytucji (od całkowitej ochrony podmiotów państwowych do formalnie jej braku), także miała wpływ na ukształtowanie się obecnej struktury branży pocztowej, traktowanej dzisiaj jako część szerszego rynku KEP.

Umownie można przyjąć, że pierwsza fala megatrendów wyznaczyła ogólne ramy działania branży pocztowej i miała charakter regulacyjno-prawny. W Polsce fala tych zmian miała miejsce od lat 90. XX (kiedy to Rzeczpospolita Polska zaczęła aspirować do UE) do 2013 r., kiedy finalnie otworzono polski rynek pocztowy na konkurencję. Drugą falę zmian $w$ otoczeniu analizowanej branży należy łączyć $\mathrm{z}$ rozwojem cywilizacyjnym, w tym technologicznym. Dla Polski, zmiany te zaczęto obserwować od drugiej dekady XXI w., podczas gdy w innych krajach UE wcześniej. Trendami wymuszającymi adaptację modeli działania w branży pocztowej do ewoluującego ich 
otoczenia są $\mathrm{z}$ całą pewnością rozwój handlu $\mathrm{w}$ sieci (e-commerce), elektronizacja $\mathrm{i}$ digitalizacja procesów, w tym tych o charakterze obsługowym klienta. Natomiast automatyzacja, robotyzacja i sztuczna inteligencja, jako ,najnowsza” fala opisywanych w artykule zmian, to elementy tzw. rewolucji 4.0, mającej już wpływ na większość współczesnych rynków i branż.

\section{Wpływ globalizacji i liberalizacji na rynek pocztowy UE}

$\mathrm{Na}$ poszczególnych rynkach mechanizmy globalizacyjne oddziaływują w różnym stopniu. Jest to uzależnione od wymagań klientów w zakresie ich upodobań w odniesieniu do danej usługi, przy jednoczesnych możliwościach przystosowania się przedsiębiorstwa do światowej konkurencji, szybkich zmian technologicznych oraz kreowania działalności w sposób globalny ${ }^{1}$.

Jednym z pierwszych zglobalizowanych rynków był rynek towarów i usług, jednak to od wymiany międzynarodowej produktów materialnych zaczął się proces liberalizacji przepływu dóbr w ramach $\mathrm{UE}^{2}$. Globalizacja rynku dóbr unijnych nabrała przyspieszenia pod wpływem działań liberalizacyjnych, przybierających postać kolejnych Dyrektyw UE, a także decyzji politycznych otwierających gospodarki krajowe, w toku wdrażania zasad wolnego handlu oraz ich instytucjonalizacji w międzynarodowym handlu. ${ }^{3}$

Rynki większości towarów i usług są już dzisiaj w pełni globalnymi, co w praktyce oznacza, że konsument $\mathrm{z}$ półkuli południowej może coś nabyć, a zamówienie jest realizowane z południowej części globu (lub na odwrót). Zamówienie może być też kompletowane $\mathrm{w}$ macierzystym kraju zamawiającego $\mathrm{z}$ elementów pochodzących $\mathrm{z}$ wielu źródeł na kilku kontynentach. Przykładem jest urządzenie oparte na zaawansowanych technologiach i technice wykonania (np. smartfon), obsługa finansowo-kadrowa firmy, czy praca w zespole składającym się z członków rozsianych po całym świecie.

Także usługi stały się przedmiotem wymiany międzynarodowej. Wiele ich segmentów staje się jednorodnych globalnie. W poszczególnych krajach i regionach, oferowane są produkty podobne pod względem standardów i użyteczności. Jednocześnie rozszerza się rynek konsumentów i zasięg światowych produktów usługowych i ich marek. Najwyraźniej obserwuje się pogłębianie globalizacji rynków usług bankowych, turystycznych, telekomunikacyjnych, ubezpieczeniowych i logistycznych. ${ }^{4}$

W branży KEP można doszukać się związków (własnościowych, organizacyjnych, czy marketingowych) z branżą TSL (transport, spedycja, logistyka), aczkolwiek obie branże mają inne, pod względem czasowym, genezy. Usługi TSL, mające swój początek w działalności transportowej, były uzupełniane o dodatkowe wartości dla klientów, które pozwoliły na wyodrębnienie się palety całościowych usług logistycznych. Oferta ta z czasem przybrała formę pełnego zlecania obsługi logistycznej wyspecjalizowanym w

\footnotetext{
${ }^{1}$ Stonehouse G., Hamill J., Campbell D., Purdie T.: Globalizacja. Strategia i zarzadzanie, Felberg, Warszawa 2001, s. 23-24.

${ }^{2}$ Europejska Wspólnota Węgla i Stali (1952-2002), pierwowzór dzisiejszej UE, jako jeden z celów obrała ułatwienia w handlu dobrami materialnymi (węglem i stalą) pomiędzy państwami członkowskimi.

${ }^{3}$ Por.: Liberska B. (red.): Globalizacja. Mechanizmy $i$ wyzwania, PWE, Warszawa 2002, s. 28.

${ }^{4}$ Haliżak E., Kuźniar R., Symonides J.: Globalizacja a stosunki międzynarodowe, Oficyna Wydawnicza Branta, Bydgoszcz - Warszawa 2003, s. 56.
} 
tym podmiotom, pochodzącym z branży transportowej (np. Shenker, wywodzący się z niemieckich kolei Deutsche Bahn). Niektórzy operatorzy KEP, w tym pocztowi, świadczą usługi TSL, jak np. Poczta Polska. Wybrani operatorzy TSL oferują usługi KEP, w tym pocztowe (przykładem DHL - część niemieckiej poczty Deutsche Post).

Nie należy zapominać o procesie regulacyjno - prawnym w UE, który stworzył „twarde” podwaliny i ramy działania dla branży pocztowej. W Polsce, rozwój usług świadczonych na całym rynku KEP, nie tylko w odniesieniu do branży pocztowej, to efekt liberalizacji, który przebiegał w kilku etapach: ${ }^{5}$

- $\quad$ tzw. I Dyrektywa Pocztowa z 1997 r., w sprawie wspólnych reguł rozwoju rynku wewnętrznego usług pocztowych Wspólnoty oraz poprawy jakości usług,

- tzw. II Dyrektywa Pocztowa z 2002 r., zmieniająca poprzednią, traktująca o dalszym otwarciu się na konkurencję wspólnotowych usług powszechnych,

- $\quad$ tzw. III Dyrektywa Pocztowa z 2080 r., odwołująca się do pierwszej w zakresie pełnego urzeczywistnienia rynku wewnętrznego usług pocztowych Wspólnoty ${ }^{6}$.

Polski rynek pocztowy ma w 2019 r., a więc po ponad 6 latach funkcjonowania w warunkach zrealizowanych założeń wynikających z ww. aktów prawnych, następującą strukturę:"

- $\quad$ Poczta Polska S.A. - operator narodowy (tzw. zasiedziały), obecny we wszystkich segmentach KEP, świadczący usługi krajowe (w oparciu o własną sieć usługową) i międzynarodowe (dzięki współpracy z innymi pocztami narodowymi),

- 142 aktywnych operatorów (tzw. alternatywnych, którzy weszli na rynek dzięki decyzjom liberalizacyjnym), świadczący usługi w wybranych lub we wszystkich segmentach KEP; w ramach pierwszych dziesięciu (pod względem ilości obsłużonych przesyłek), są podmioty oferujące usługi globalne (DHL, amerykańskie FedEx i UPS), międzynarodowe (holenderskie GLS i TNT, polskie InPost Paczkomaty i InPost Express) i krajowe (niemiecki Geis Parcel i francuski DPD); poza tym, działa wiele mniejszych firm o zasięgu lokalnym, specjalizujących się, np. w danym rodzaju usług, jak. doręczenie „od drzwi do drzwi”, realizowane na określonym obszarze, np. jednego miasta lub aglomeracji.

Najwięksi operatorzy pocztowi, jak Deutsche Post DHL, UPS, czy FedEx to globalne korporacje, obecne właściwie we wszystkich krajach świata, dzięki zintegrowaniu wokół siebie mniejszych podmiotów. Pakiet usług, oferowany przez taką korporację, wychodzi nie tylko daleko poza usługi pocztowe, ale także wykracza poza zakres produktów KEP.

\footnotetext{
5 Zob.: Budziewicz-Guźlecka A., Czaplewski M., Drab-Kurowska A.: Integracja sektorowa wybranych europejskich rynków pocztowych $i$ telekomunikacyjnych $w$ warunkach globalizacji, edu-Libri, KrakówLegionowo 2018, s. 44.

${ }^{6}$ Dla Polski, Dyrektywa ta była o tyle istotna, że wyznaczyła daty finalnego otwarcia pocztowych rynków krajowych na konkurencję. Najpóźniejszą, dostępną datą był 1 stycznia 2013 r. i Polska skorzystała z tej opcji, otwierając swój rynek jako jeden z ostatnich krajów UE.

${ }^{7}$ Por.: Raport o stanie rynku pocztowego w 2017 roku, Urząd Komunikacji Elektronicznej, Warszawa 2018, s. 11 i 15, źródło elektroniczne: https://bip.uke.gov.pl/raporty/raport-o-stanie-rynku-pocztowego-w-2017roku,16.html (dostęp: 21.02.2019). Szczegółową charakterystykę przedmiotowego rynku można znaleźć w: Michalski K.: Rynek pocztowy - przyczynek do badań z perspektywy zarzqdzania, „Ekonomiczne Problemy Usług" nr 130, Zeszyty Naukowe Uniwersytetu Szczecińskiego, Szczecin 2018, s. 89-97, DOI: 10.18276/epu.2018.130-09.
} 
Korporacje są skuteczna odpowiedzią na jakościowe zmiany w technice przesyłania informacji, zmiany roli poszczególnych czynników produkcji i sposobem na dostosowanie się do praktyki międzynarodowych stosunków gospodarczych, mających na celu swobodne rozporządzanie produkcją na globalnym rynku. W procesach globalizacyjnych konkurencyjne stają się te podmioty, które potrafią skutecznie wykorzystywać systemy informatyczne i telekomunikacyjne w poznawaniu i korzystaniu ze światowego rynku czynników produkcji i zbytu, a także traktują posiadanie kapitału intelektualnego i dbanie o jego wydajność jako podstawę długookresowej przewagi. Ekspansja korporacji jest nie tylko skutkiem liberalizacji międzynarodowych stosunków ekonomicznych, ale jest też samodzielnym czynnikiem przyspieszającym, a nawet wymuszającym liberalizację ${ }^{8}$.

Im silniejsza obecność danego usługodawcy na danym rynku, tym dla niego dostęp Najsilniejsi operatorzy pocztowi, wpisują się w trend globalnej dostępności swoich produktów. Możliwości wyboru dostawcy usługi (operator narodowy, czy alternatywny), rodzaju usługi (kurierska, ekspresowa, paczka, inna), standardu terminowości (od doręczenia natychmiastowego do zrealizowanego, np. za 3-5 dni), jak i sposobu wykonania (do rąk własnych, do punktu odbioru, a nawet do wskazanego bagażnika samochodu lub terenu posesji), jest bardzo szeroki.

\section{Współdzielenie, technologie a rozwój działalności usługowej}

Idea współdzielenia (sharing), oparta na korzystaniu ze wspólnych, udostępnianych zasobów, rozwija się. Ekonomia współdzielenia (sharing economy) to wyłaniająca się z tej idei szkoła ekonomii, w której można doszukiwać się poglądów Arystotelesa: „,Na ogól, z używania można czerpać więcej pożytku niż z posiadania",. W aspekcie logistycznym, idea ta przyjmuje założenie „,korzystanie zamiast posiadania”. Wyrazem zmienionego podejścia do zasobów są usługi komercyjne, jak np. car sharing, flat sharing, cloud computing, czy system-as-a service. Każda elastyczna, wiarygodna i prężnie działająca organizacja, zwłaszcza ta globalna, ma więcej możliwości korzystania z zasobów na zasadzie dostępu (subskrypcji, umowy ramowej, kontraktowania itd.).

Sprowadzając koncepcję współdzielenia do branży pocztowej, korzystanie ze wspólnego łańcucha stwarza możliwość przekazywania „swoich” przesyłek do „cudzej” sieci powiązań w łańcuchu dostaw. I tak, przesyłka odebrana w Polsce przeznaczona do adresata, np. w Wietnamie, może być odebrana przez kuriera na rowerze z miejskiej firmy kurierskiej, a następnie trafić do sieci logistycznej UPS, który zrealizuje przewóz interkontynentalny. Odbiorca w Azji otrzyma natomiast przesyłkę za pośrednictwem lokalnego kuriera lub publicznej poczty, dostarczającej przesyłki, np. z użyciem łodzi.

Szanse wynikające z korzystania ze wspólnych zasobów, nie tylko materialnych, ale też koncepcji, pomysłów, czy projektów, są tym bardziej istotne, gdy połączy się je z przełomowymi technologiami i rozwiązaniami technicznymi. Krytycznym czynnikiem rozwoju, który wspiera procesy globalizacji, w tym usług świadczonych przez operatorów pocztowych, jest postęp, w tym w zakresie nowych technologii

\footnotetext{
${ }^{8}$ Szymański W.: Globalizacja - wyzwania i zagrożenia, Difin, Warszawa 2001, s. 32-33.

${ }^{9}$ Rudawska I.: Ekonomia dzielenia się, czyli konsumpcja współdzielona i inne formy alternatywnego dostęu do dóbr, „Studia Ekonomiczne” nr 254, Zeszyty Naukowe Uniwersytetu Ekonomicznego w Katowicach, Katowice 2016, s. 181 .
} 
informacyjnych. Internet i komunikacja elektroniczna, telefonia komórkowa, aktywności w sieci (e-biznes) to już standardowe pola działania, które umożliwiły przyspieszenie globalnych kontaktów biznesowych, wspieranych przez usługi przesyłu informacji i towarów. Światowy system komunikowania się pozwala na błyskawiczny przepływ idei, towarów, informacji, kapitału i pozostałych zasobów.

Globalna rewolucja informacyjna wsparła możliwości świadczenia usług. Sektory, które wcześniej nie miały wielkiego udziału w wymianie międzynarodowej, obecnie osiaggaja globalny zasięg. Rozwój technologii dał możliwości zarządzania produkcją w filiach na całym świecie. Procesy globalizacji spowodowały dazżenie do tworzenia i wykorzystywania zaawansowanej techniki, a postęp technologiczny przyśpieszył jeszcze bardziej rozwój procesów globalizacji. ${ }^{10}$

Odnosząc się do branży KEP, trudno wyobrazić sobie zamówienie jakiegokolwiek towaru, czy wysłania wiadomości, bez użycia urządzenia mobilnego, z możliwością odbioru przesyłki lub wiadomości w czasie i miejscu dogodnym dla zamawiającego. Prognozy dla handlu internetowego, opartego na wykorzystywaniu mobilnych technologii (55\% transakcji w 2018 r. przypadało na urządzenia typu smartfon), są znakomite, dla Polski oparte są one na tempie wzrostu ponad $25 \%$ rok do roku ${ }^{11}$.

Ilość przesyłek KEP w światowym obrocie wiąże się z rozwojem rynku TSL, określanym jako barometr gospodarki. Pomiędzy oboma rynkami występuje efekt mnożnikowy: zwiększona skala obsługi logistycznej to większe zapotrzebowanie na „mniejsze” usługi, w tym na dostarczanie przesyłek z zamówieniami, czy z różnego rodzaju korespondencją np. rozliczeniami, fakturami itp. Prognozy dla polskiego rynku TSL są również korzystne, np. w zakresie pracy przewozowej transportu samochodowego, czy powierzchni magazynowej w dyspozycji $1^{12}$.

Rozwój technologiczny człowieka to nie tylko całościowe systemy oplatające procesy $\mathrm{w}$ organizacji ${ }^{13}$ i coraz szybsze, bardziej skuteczne, tańsze i powszechnie dostępne technologie ${ }^{14}$, adaptowalne przez różnego rodzaju systemy gospodarcze i inne. Rozwój technologiczny to przede wszystkim strukturalne i wieloaspektowe zmiany jakościowe w zakresie schematów i modeli działań, nawyków i zachowań konsumenta, na większości płaszczyzn jego aktywności. Tworzą się nowe możliwości życia i działania, ale wyłaniają się również poważne zagrożenia dla człowieka, nawet o charakterze dehumanizacji. Wyrazem tych obaw są wizje przejmowania ludzkich aktywności przez maszyny i roboty. Niektórzy futuryści pisali o niektórych aspektach

${ }^{10}$ Zob.: Sitko-Lutek A. (red.): Polskie firmy wobec globalizacji. Luka kompetencyjna, PWN, Warszawa 2007, s. $9-11$.

${ }^{11}$ Mazurkiewicz P.: Telefony dobija sklepy stacjonarne, „Rzeczpospolita” z dn. 18.02.2019, s. A18-A19.

${ }^{12}$ Przybylski R., Dobre prognozy dla branży TSL, ,Rzeczpospolita” z dn. 15.02.2019, s. A23.

${ }^{13}$ Zob.: Kisielnicki J., Pańkowska M., Sroka H. (red.): Zintegrowane systemy informatyczne, Wydawnictwo Naukowe PWN, Warszawa 2012.

${ }^{14}$ Zob. m.in.: Długosz J. (red.), Nowoczesne technologie w logistyce, PWE, Warszawa 2009; Kozłowski R., Sikorski A. (red.): Nowoczesne rozwiqzania w logistyce. Wyd. II, Wolters Kluwers Warszawa 2013; Ocicka B. (red.): Technologie mobilne $w$ logistyce i zarzqdzaniu tańcuchem dostaw, Wydawnictwo Naukowe PWN, Warszawa 2017. 
tych zmian już wiele lat temu ${ }^{15}$, a wciąż konstruowane są kolejne prognozy, wzmacniane stanem dzisiejszej wiedzy ${ }^{16}$.

W opinii menedżerów IT firm high-tech, najistotniejszymi rozwiązaniami, mającymi największe wpływ na różnego rodzaju procesy, są (odsetek odpowiadających): ${ }^{17}$

- $\quad 74 \%$ - chmura (Cloud) - w modelu SaaS,

- $\quad 74 \%$ - urządzenia mobilne i aplikacje

- $\quad 73 \%$ - platformy marketingowe,

- $\quad 71 \%$ - Internet rzeczy (Internet of Things)

- $\quad 71 \%$ - sztuczna inteligencja (AI)

- $\quad 71 \%$ - media społecznościowe (social media),

- $\quad 69 \%$ - płatności cyfrowe,

- $\quad 67 \%$ - rzeczywistość rozszerzona (AR - Augmented Reality)

- $\quad 64 \%$ - robotyka (systemy automatyki wraz z autonomicznymi samochodami).

To samo badanie pokazało jednak, że: ${ }^{18}$

- $\quad 1 / 3$ respondentów stwierdziło, że ich organizacja jest przygotowana na korzyści z dostępu do ,przełamujących” technologii, z czego 31\% wie, jakie rozwiązania są dostępne, a 29\% uważa, że ma kompetencje aby wiedzę wykorzystać w praktyce,

- $22 \%$ twierdzi, że rozumie, tworzy i zarządza strategicznymi scenariuszami biznesowymi na bazie już posiadanych danych.

Wpływ technologii na współczesne organizacje ma wieloaspektowy i trudny do precyzyjnego zdefiniowania zasięg. Ale jedno można stwierdzić, że zmiany te zmuszają organizacje uczące się do przedefiniowywania swoich strategii, tak aby nadążyć za wyzwaniami rynkowymi, a także koniecznymi zmianami społecznymi wewnątrz nich ${ }^{19}$.

\section{Rozwój cywilizacyjny a komunikowanie się}

Najbardziej istotne z perspektywy obszaru badawczego artykułu są zmiany w sposobach komunikowania się i wymiany towarowej. Chodzi tu nie tylko o porozumiewanie się pomiędzy ludźmi (co w pewnym, choć coraz mniejszym zakresie, zapewniają tradycyjne usługi pocztowe). Zmiany te dotyczą podmiotów komunikowania się, którymi stały się już maszyny, roboty i pojazdy. W tym znaczeniu, przyszłe, powszechne technologie prawdopodobnie całkowicie wyeliminują tradycyjne sposoby komunikowania się poprzez, np. list. Technologie mogą też poważnie ograniczyć zapotrzebowanie na przesyłanie towarów na odległość w formie przesyłki, gdyż zagrożeniem dla nich będą drukarki 3D lub kolejnych generacji, umożliwiające samodzielne „,wytworzenie” towaru, wcześniej zamówionego poprzez platformę sprzedażową, odpowiednika dzisiejszych Amazon lub AliExpress. Przesyłki paczkowe, czy kureirskie, które dzisiaj są wyrazem

\footnotetext{
${ }^{15}$ Zob.: Toffler A.: Trzecia fala, Wydawnictwo KURPISZ S.A., Poznań 2006. Książka została wydana po raz pierwszy w $1980 \mathrm{r}$

${ }^{16}$ Zob.: Harari Y.N., 21 lekcji na XXI w., Wydawnictwo Literackie, Kraków 2018.

${ }^{17}$ Badanie Forrester Consulting na zlecenie KPMG, 2016. Za: Elert B.: Czas galopujacych technologii,

„Logistics Manager”, październik - listopad 2017, s. 78.

${ }^{18}$ Ibidem,

${ }^{19}$ Goldman Sachs The Internet of Things. Making sense of the next mega-trend, 2014. Za: Ibidem.
} 
boomu e-handlu, mogą stracić na znaczeniu, co jest dowodem na to, że dzisiejsze trendy mogą nie być trwałymi.

Niepewność, a nawet gwałtowność zmian w otoczeniu to kolejne cechy dziejącej się obecnie „rewolucji”. Aby przekonać się do takiej charakterystyki zmian wystarczy zapoznać się z definicjami trendów odnoszących się do charakteru relacji człowieka $\mathrm{z}$ technologiami. Relacje te, być może dzisiaj wydające się wciąż zbyt fantastyczne, pozwalają jednak zarysować sobie ramy całkowicie nowego porządku świata, opartego na takich trendach jak: stawanie się, kognifikacja, krążenie, korzystanie z ekranów, uzyskiwanie dostępu, udostępnianie, filtrowanie, remiksowanie, interakcje, monitorowanie, zadawanie pytań, zaczynanie od początku ${ }^{20}$. Uważa się, że obecne zmiany w sposób zasadniczy zmienią sposób życia i pracy, a charakterystyczne dla nich nowe technologie, łączące świat materialny, cyfrowy i biologiczny człowieka, wpłyną na wszystkie dziedziny gospodarki, branże i rządy, które muszą rzucić wyzwanie samej istocie pojmowania człowieczeństwa ${ }^{21}$.

Nie można jednak rozpatrywać zmian technologicznych, bez tych o charakterze społecznym. W tym zakresie, zauważono powstanie specyficznej kultury życia opartej na chęci natychmiastowej satysfakcji, napędzanej także niecierpliwością odnośnie dostępu do dóbr materialnych (on demand) (22 $^{2}$. Taki styl życia, w tym konsumpcji, to już konkretne wyzwania dla producentów i dostawców, którzy odpowiedzialni są za dostarczenie dobra do miejsca jego użycia czy zużycia. W świetle tych zmian, można postawić pytanie o wpływ zarysowanej wyżej rzeczywistości na procesy logistyczne, na których oparte jest świadczenie usług KEP, w tym tych dostarczanych przez operatorów pocztowych. Można bowiem zacząć wątpić, czy w perspektywie kilku, czy kilkunastu dekad, logistyka, oparta na fizycznym przemieszczaniu fizycznych obiektów, będzie w ogóle potrzebna?

\section{Logistyka 4.0 a branża KEP}

W historii powszechnej świata możemy zidentyfikować milowe kroki w jego rozwoju, utożsamiane z konkretnymi wynalazkami o przełomowym charakterze: silnik parowy, samochód, komputer i globalna sieć komunikacyjna (rys. 1).

\footnotetext{
${ }^{20}$ Zob.: Kelly K.: Nieuniknione. Jak inteligentne technologie zmieniq nasza przysztość, Poltext, Warszawa 2017.

${ }^{21}$ Oczywiście, nie należy zapominać o zagrożeniach wynikających z porządku świata, gdzie wszechobecne maszyny, systemy i algorytmy będą stopniowo przejmować spełniane przez człowieka role społeczne, wykonywane zawody, czy zajmowane stanowiska. Także wizje konfliktu człowieka z maszynami nie są pozbawione sensu i nieuzasadnione. Otwiera to więc pole do odrębnych badań, które już są prowadzone, np. w zakresie bezpieczeństwa cybernetycznego. Zob. szerzej: Schwab K.: Czwarta rewolucja przemystowa, Studio Emka, Warszawa 2018.

${ }^{22}$ Bartkiewicz A., Życie na żqdanie, ,Rzeczpospolita - Plus Minus” z dn. 19-20 maja 2018, s. 5-7.
} 



Rysunek 1. Etapy w rozwoju ludzkości

Źródło: http://przemysl-40.pl/index.php/2017/03/22/czym-jest-przemysl-4-0/ [dostęp: 24.02.2018].

Logistyka w wersji 4.0, będąca elementem Przemysłu 4.0, oparta będzie nie tylko na współdziałaniu maszyn i ludzi oraz współdzieleniu przez nich zasobów, ale także na integracji działań $\mathrm{w}$ jednej globalnej sieci. W integracji tej udział mieć będzie także sztuczna inteligencja, posiadająca prawdopodobnie kompetencje do podejmowania decyzji za człowieka. Nowa inteligencja będzie posiadała również możliwości samodoskonalenia się, a co za tym idzie, będzie mogła zwiększać swoją autonomię.

Menedżerowie, zarządzający Przemysłem 4.0 i jego procesami, są zmuszeni do dostosowania swojego działania do wymogów nowych technologii: wytwórczych, komunikacyjnych, czy informacyjnych, chociażby z powodu stopniowego zamieniania kanałów fizycznych przepływów informacji na elektroniczne. W toku dalszych zmian, coraz lepsze współdziałanie wszystkich elementów, tworzące zintegrowaną sieć połączeń, określaną jako Internet Rzeczy (Internet of Things), będzie przemawiać za kolejnymi pracami nad coraz to nowszymi sieciami powiązań i rodzajami relacji, bardziej wydajnymi, produktywnymi i skracającymi czas reakcji na potrzeby klienta, w tym usług operatorów pocztowych.

\section{Komodyzacja tradycyjnej usługi pocztowej}

Podstawowa działalność usługowa poczty polega na dostarczaniu pod wskazany przez nadawcę adres różnego rodzaju przesyłek, zawierających materialny przedmiot (towar) i (lub) informację zapisaną w formie korespondencji. Usługi pocztowe, a później KEP, wzięły swój początek w działalności tworzonych przez poszczególne państwa organizacji pocztowych. Jednostki te dostarczały najpierw korespondencję w formie, np. listu. Z czasem, w ślad za rozwojem współpracy politycznej i gospodarczej pomiędzy państwami, organizacje pocztowe zaczęły dostarczać także fizyczne dobra, przesyłane w postaci, np. paczki.

Odnośnie branży pocztowej mamy do czynienia ze zjawiskiem komodyzacji, czyli utraty wartości przez dobro dotychczas luksusowe, czy niezastapione z punktu widzenia zaspokajania danego rodzaju potrzeb ${ }^{23}$. Utrata wartości dotyczy tradycyjnych usług pocztowych: listów i „podstawowych” paczek - w rozumieniu prostego odbioru i

${ }^{23}$ Ze zjawiskiem komodyzacji mamy do czynienia w przypadku wielu innych usług, np. kolejowych (zarówno w zakresie przewozów pasażerskich, jak i towarowych), telewizyjnych, czy radiowych. 
dostarczenia przesyłki pod wskazany adres, bez żadnych dodatkowych elementów. Z racji opisanych czynników: cywilizacyjnych, technologicznych, czy społecznych, usługi listowe utraciły status niezastąpionych: już teraz komunikować się można szybciej, taniej i skuteczniej poprzez różnorodne kanały elektronicznie a możliwości te będą zdecydowanie wzrastać.

Jedna $\mathrm{z}$ usług komunikacyjnych oferowanych przez przedsiębiorstwa pocztowe, jakim był telegram, zniknął już całkowicie. Globalna liczba wysyłanych listów spada także w Polsce (rys. 2). Trend ten potwierdzają dane z ostatnich lat - listów jest coraz mniej w obrocie, spadek postępuje niezaprzeczalnie ${ }^{24}$.

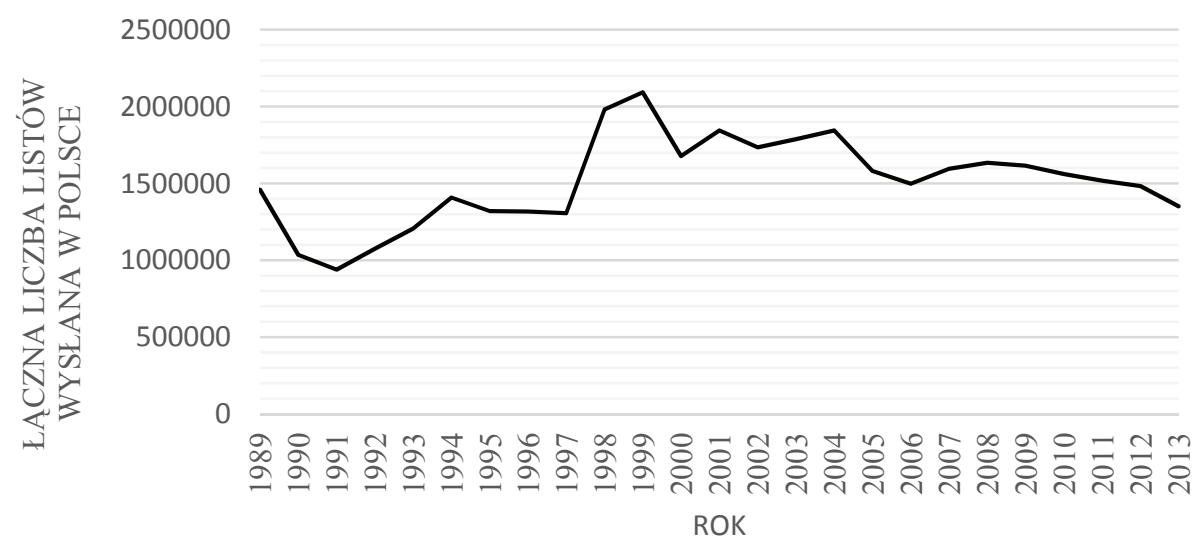

Rysunek 2. Liczba listów wysłanych w Polsce w latach 1989-2013

Źródło: opracowanie własne na podstawie: Chyż B.: Ludzie listów już nie piszq... Zobacz, ile wysłaliśsmy ich przez ostanie 50 lat, źródło elektroniczne: www.biqdata.wyborcza.pl/ludzie-listy-pisza-nie-juz-nie-pisza-ilewysylalismy-tradycyjnych-listow-przez-ostatnie-50-lat [dostęp: 03.08.2017].

W przypadku szeroko rozumianych paczek, komodyzacja nie dotyczy bezpośrednio ich ilości w obrocie, wręcz odwrotnie, wolumeny paczek rosną, do czego przyczyniają się e-zakupy. W przypadku paczek, zjawisko utraty wartości wymusza na podmiotach KEP, w tym silnych na tym rynku operatorach pocztowych, potrzebę ciagłego poszukiwania nowych elementów, nie tylko logistycznych, ale także cenowych, marketingowych, promocyjnych itd., które mają zadanie jeszcze lepiej spełnić wymagania konsumentów.

Komodyzacja usług pocztowych dotyczy wyraźnie poczt narodowych, wielkich, państwowych molochów, które przez kilkadziesiąt, a nawet kilkaset lat, były jedynymi podmiotami, które miały prawo do prowadzenia działalności pocztowej. Oferta usługowa operatorów pocztowych obejmowała - odnosząc się do dzisiejszego rynku KEP - tylko listy i paczki, które zaspokajały całkowicie potrzeby komunikacyjne

${ }^{24}$ Duszczyk M., Ceny ushug pocztowych sq za niskie, „Rzeczpospolita” z dn. 21 lutego 2019, s. A27. 
społeczeństwa i państwa. Listy i paczki ${ }^{25}$ były jedyną i podstawową działalnością pocztowa.

Współcześnie, działalność na rynku KEP opiera się wciąż na fizycznym dostarczaniu pod wskazany adres różnego rodzaju przesyłek. Ale zmieniają się kanały za pomocą których te przesyłki trafiają do adresata. W przypadku korespondencji, fizycznie dostarczona przesyłka może zostać zamieniona na wersję elektroniczna, wydrukowana na końcowym etapie procesu i znów posiadać postać fizyczną. Przesyłka ta może też trafić w wersji elektronicznej pod wskazany adres (skrzynkę pocztową).

W przypadku przesyłek zmieniają się również wykonawcy procesów: nie tylko człowiek, ale i maszyna (robot, dron), a być może niedługo, także autonomiczny pojazd, będą na szeroką skalę odbierać i dostarczać fizycznie przesyłki. Te wszystkie zmiany wymuszają konieczność dostarczania odbiorcom usług KEP wartości, których oczekuja, a one wykraczaja poza te podstawowe, ,od zawsze" dostarczane przez usługi poczty, czyli terminowe $\mathrm{i}$ bezpieczne dostarczenie przesyłki. To zdecydowanie za mało dla współczesnego klienta, dokonującego zakupów w Internecie i oczekującego możliwości swobodnego kształtowania nie tylko miejsca i czasu odbioru przesyłki ${ }^{26}$, ale też fizycznej postaci produktu znajdującego się w środku, np. paczki. Ten ostatni rodzaj oczekiwania wobec usługi KEP wymaga już ścisłej, szerszej współpracy operatora $\mathrm{z}$ wytwórcą $\mathrm{w}$ łańcuchu dostaw i takiego umiejscowienia się $\mathrm{w}$ nim, aby móc być dostawcą nie tylko pożądanego towaru, ale także emocji związanych $\mathrm{z}$ zakupem i odbiorem.

\section{Podsumowanie}

W przypadku pocztowych operatorów narodowych, ich struktury organizacyjne i procesy, nie tylko logistyczne, nie są na tyle płaskie, elastyczne i „szybkie”, aby móc już dzisiaj skutecznie odpowiedzieć na zarysowane w artykule trendy. Pocztowi operatorzy narodowi we wszystkich krajach UE to co najmniej duże przedsiębiorstwa państwowe, działające $\mathrm{w}$ wielu segmentach rynku, oferujące wiele różnych produktów. Podstawowym produktem branży pocztowej pozostaje jednak pocztowa usługa powszechna, zapewniająca społeczeństwu swobodny dostęp do podstawowych usług pocztowych na terenie całego kraju, bez dyskryminacji żadnej jego części pod względem ekonomicznym (dostępność cenowa) i logistycznym (dostępność czasowa i przestrzenna).

Odnosząc się publicznego operatora pocztowego w Polsce, jakim jest Poczta Polska, wyzwaniem dla niej, w kontekście bieżącego funkcjonowania na rynku KEP, jest przede wszystkim znalezienie odpowiedzi na kluczowe pytania w zakresie zarządzania na poziomie operacyjnym:

- jak zorganizować logistykę (system i procesy) niezbędną do obsługi podmiotów handlujących w sieci (np. sklepów): powierzchnie do składowania i kompletowania zleceń, jak też logistykę dla obsługi przesyłek generowanych w sieci (zamawiający),

\footnotetext{
${ }^{25}$ A także usługi finansowe.

${ }^{26}$ Zob. szerzej: Kawa A.: Logistyka jako instrument kreowania wartości dla klienta we handlu elektronicznym, „Przedsiębiorczość i Zarządzanie” 4/2017, część II.
} 
- jak zarządzać przepływami wielu różnych strumieni przesyłek (paczek, kurierskich, listowych, innych), generowanych przez e-commerce, w jednym, ogromnym organizmie, jakim jest sieć logistyczna obejmująca cały kraj i zawierająca ponad 10 tys. punktów odbioru, sortowania i odbioru przesyłek?

Odnosząc się do drugiego, powyższego dylematu, można przyjąć proste założenie o rozdziale całego przedsiębiorstwa i jego sieci logistycznej na część ,powszechną" i „niepowszechną" (komercyjną), w ramach której znalazłaby się większość usług $\mathrm{KEP}^{27}$. Ale problem dla Poczty Polskiej jest szerszy, gdyż dotyczy on wyborów strategicznych, przede wszystkim jaki model zarządzania może zapewnić warunki aby działań efektywnie, tj. przynosić zysk, w warunkach społecznej misji postawionej przez państwo członkowskie UE swojemu operatorowi narodowemu.

W konsekwencji, dostawcy tych usług muszą przedefiniować cele swoich produktów, przeorientować swoje modele biznesowe, być może „wymyśleć się” na nowo na dotychczasowych, czy przyszłych rynkach. Istotnym wyzwaniem dla takiego przedsiębiorstwa jak Poczta Polska, ale także, np. dla Polskich Kolei Państwowych, czy Telewizji Polskiej, jest konieczność ciagłego poszukiwania konsensusu pomiędzy dwoma rodzajami wartości w zarządzaniu i wynikających z tych celów stawianych do osiaggania. Misja społeczna, jaką każde z tych usługodawców musi realizować, a z drugiej strony, twarde oczekiwania wobec wyników finansowych, ekonomicznych, rynkowych itd., stanowią konkretne wyzwania stojące przed zarządzającymi tymi organizacjami. To wyzwanie już dzisiaj przenosi się na poziom codziennych wyborów, ale jest o wiele bardziej istotne w kontekście przyszłości, bądź co bądź, istotnych usług o charakterze społecznym, gwarantowanych przez każde państwo członkowskie UE.

Organizacje takie jak państwowa poczta, koleje, czy media, są organizacjami gdzie wpływ państwa jest silny, dotyczy to nie tylko Polski. Z jednej strony jest to korzystne dla tego rodzaju spółek, gdyż w praktyce oznacza dla nich taką bądź inną formę ochrony, w tym finansowej, ze strony państwa. Z drugiej natomiast strony, wdrażanie długofalowych zmian w tak specyficznych, pod względem zakresu i skali działania, hierarchiczności i procesów decyzyjnych, organizacjach jest co najmniej utrudnione. W polskiej praktyce, zmiany o strategicznym charakterze dla spółek skarbu państwa, są przeważnie przerywane, negowane, czy modyfikowane w trakcie wdrażania, tracąc tym samym pierwotny kształt założeń, nie mówiąc o samym impecie procesu implementacji.

Trudno przewidywać, aby w najbliższych kilku latach, Poczta Polska była organizacją, która dokona istotnego skoku technologicznego, czego wyrazem byłoby np. wdrożenie nowoczesnych rozwiązań w zakresie świadczonych usług, co można zaobserwować w praktyce działań operatorów skandynawskich. ${ }^{28}$ Polski operator publiczny może i powinien natomiast zrobić wszystko aby mieć faktyczną autonomię działania pozwalająca jej np. na kreowanie możliwości współpracy $\mathrm{z}$ innymi uczestnikami rynku KEP, czy TSL, gdzie większość operatorów nie posiada własnej floty przewozowej (samochody są przeważnie własnością podwykonawcy, np.

\footnotetext{
${ }^{27}$ Model taki funkcjonuje w Niemczech, gdzie Deutsche Post AG jest odpowiedzialna za usługę powszechną, a usługi KEP i TSL są realizowane przez dwie inne jednostki biznesowe (dywizje).

${ }_{28}^{28}$ Michalski K.: Ustugi logistyczne na poczcie - doświadczenia skandynawskie, „Logistyka”, nr 2/2019, s. 4648.
} 
przewoźnika, czy kuriera). Tymczasem, Poczta Polska posiada własną flotę kilku tysięcy samochodów, które nie są wykorzystywane w 100\%. Brak jest tym samym jakichkolwiek przesłanek biznesowych przemawiających za utrzymywaniem takiego stanu rzeczy.

Wydaje się, że Poczta Polska, odznacza się, jako organizacja, niską świadomością nieuchronności zmian, które dalej będą działać na jej niekorzyść. Należy przyjąć, że takie przedsiębiorstwo jak Poczta Polska jest potrzebne państwu do spełniania jego funkcji. Jednak wciąż powszechne jest myślenie o polskim operatorze w kategoriach urzędu, czy instytucji. Poczta Polska to jeden z największych, o ile nie największy, operator logistyczny w kraju, wychodzący poza jego granice, który powinien być zarządzany zgodnie $\mathrm{z}$ pewnymi zasadami (paradygmatami), np. w odniesieniu do dostarczanej jakości usług. Menedżer logistyki myśli bowiem o jakości w kategoriach „value for money”, tymczasem w Poczcie Polskiej obowiązuje podejście ,jakość za wszelką cenę", co można zaobserwować, np. w odniesieniu do sposobu planowania sieci logistycznej i realizowanej wewnątrz niej przepływów strumieni przesyłek. Gdy organizacja nie posiada realnego wsparcia w zakresie informatyzacji procesów planistycznych, dochodzi do planowania „na zapas”, także jakości odbiorów i dostaw, czego praktycznym wyrazem jest dążność do $100 \%$ terminowości. Poczta Polska w zakresie usług powszechnych nie jest zobligowana do takiego wykonania usługi. Tym samym, brak jest po raz kolejny, w odniesieniu do polskiego operatora, racjonalnych przesłanek dalszego utrzymywania tak niekorzystnego dla niego podejścia. Warunkiem zmiany podejścia $\mathrm{w}$ tej kwestii jest posiadanie odpowiedniego narzędzia informatycznego do modelowania logistyki. ${ }^{29}$

Podsumowując, większość krytycznych wyzwań stojących obecnie przed uczestnikami branży pocztowej, dotyczy konieczności zmian na poziomie zarządzania organizacją, tak aby była zdolna do skutecznych działań w coraz szybszym i zmiennym środowisku. Oczywiście, dla Poczty Polskiej, warunkiem wstępnym jest transformacja $\mathrm{z}$ instytucji w przedsiębiorstwo rynkowe. Płaska struktura, krótki proces decyzyjny, szybka reakcja na sygnały z rynku to dla takiej organizacji jak Poczta Polska, wciąż wyzwanie na przyszłość. Tymczasem, zmiany toczące się $\mathrm{w}$ otoczeniu polskiego operatora mają charakter cywilizacyjnego postępu, zmieniającego całkowicie metody i techniki, w tym kanały, komunikacji. Nieuchronność zmian opisanych w artykule wzbudzają uzasadnione wątpliwości co do funkcjonowania Poczty Polskiej w obecnym kształcie w dłuższej perspektywie. Nie bez znaczenia pozostaje jakość samego zarządzania w Poczcie Polskiej, której wysokiego poziomu nie sposób osiagnąć bez wysokich kompetencji menedżerów tworzących każdą organizację.

\section{Bibliografia}

Bartkiewicz A., Życie na żqdanie, „Rzeczpospolita - Plus Minus” z dn. 19-20 maja 2018.

Budziewicz-Guźlecka A., Czaplewski M., Drab-Kurowska A.: Integracja sektorowa wybranych europejskich rynków pocztowych $i$ telekomunikacyjnych $w$ warunkach globalizacji, edu-Libri, Kraków-Legionowo 2018.

29 Zob.: Michalski K., Koncepcja wsparcia informatycznego procesu planowania logistyki operatora pocztowego, ,, Marketing i Rynek”, nr 12, s. 265-276 (CD). 
Chyż B.: Ludzie listów już nie piszq... Zobacz, ile wysłaliśmy ich przez ostanie 50 lat, źródło elektroniczne: www.biqdata.wyborcza.p1/ludzie-listy-pisza-nie-juz-nie-pisza-ile-wysylalismytradycyjnych-listow-przez-ostatnie-50-lat (dostęp: 03.08.2017).

Dembińska I., Frankowska M., Malinowska M., Tundys B.: Smart logistics, edu-Libri, KrakówLegionowo 2018.

Długosz J. (red.), Nowoczesne technologie w logistyce, PWE, Warszawa 2009.

Duszczyk M., Ceny ustug pocztowych sq za niskie, „Rzeczpospolita” z dn. 21 lutego 2019.

Elert B.: Czas galopujacych technologii, „Logistics Manager”, październik - listopad 2017.

Haliżak E., Kuźniar R., Symonides J.: Globalizacja a stosunki międzynarodowe, Oficyna Wydawnicza Branta, Bydgoszcz - Warszawa 2003.

Harari Y.N., 21 lekcji na XXI w., Wydawnictwo Literackie, Kraków 2018.

Kawa A.: Logistyka jako instrument kreowania wartości dla klienta we handlu elektronicznym, „Przedsiębiorczość i Zarządzanie” 4/2017, część II.

Kelly K.: Nieuniknione. Jak inteligentne technologie zmieniq nasza przyszłość, Poltext, Warszawa 2017.

Kisielnicki J., Pańkowska M., Sroka H. (red.): Zintegrowane systemy informatyczne, Wydawnictwo Naukowe PWN, Warszawa 2012.

Kozłowski R., Sikorski A. (red.): Nowoczesne rozwiazania w logistyce. Wyd. II, Wolters Kluwers Warszawa 2013.

Liberska B. (red.): Globalizacja. Mechanizmy i wyzwania, PWE, Warszawa 2002.

Raport o stanie rynku pocztowego w 2017 roku, UKE, Warszawa 2018.

Mazurkiewicz P.: Telefony dobija sklepy stacjonarne, „Rzeczpospolita” z dn. 18.02.2019.

Michalski K., Koncepcja wsparcia informatycznego procesu planowania logistyki operatora pocztowego, ,, Marketing i Rynek”, nr 12, s. 265-276 (CD).

Michalski K.: Rynek pocztowy - przyczynek do badań z perspektywy zarzqdzania, „Ekonomiczne Problemy Usług" nr 130, Zeszyty Naukowe Uniwersytetu Szczecińskiego, Szczecin 2018, s. 8997, DOI: 10.18276/epu.2018.130-09.

Michalski K.: Ustugi logistyczne na poczcie - doświadczenia skandynawskie, „Logistyka”, nr 2/2019, s. 46-48.

Ocicka B. (red.): Technologie mobilne $w$ logistyce $i$ zarzqdzaniu tańcuchem dostaw, Wydawnictwo Naukowe PWN, Warszawa 2017.

Przybylski R., Dobre prognozy dla branży TSL, „Rzeczpospolita” z dn. 15.02.2019.

Rudawska I.: Ekonomia dzielenia się, czyli konsumpcja współdzielona i inne formy alternatywnego dostęu do dóbr, „Studia Ekonomiczne” nr 254, Zeszyty Naukowe Uniwersytetu Ekonomicznego w Katowicach, Katowice 2016.

Schwab K.: Czwarta rewolucja przemystowa, Studio Emka, Warszawa 2018.

Sitko-Lutek A. (red.): Polskie firmy wobec globalizacji. Luka kompetencyjna, PWN, Warszawa 2007.

Szymański W.: Globalizacja-wyzwania i zagrożenia, Difin, Warszawa 2001.

Toffler A.: Trzecia fala, Wydawnictwo KURPISZ S.A., Poznań 2006.

\section{Summary}

The postal industry, whose historical product are letter and parcel, is now treated as a part of the wider CEP market (courier, express, parcel). It is possible to identify, for the CEP market, development phenomena (megatrends) affecting its long-term functioning. The knowledge of these phenomena should be the basis for any strategic decision.

The aim of the study is to systematize the essence of changes taking place in the environment of the postal industry. Some phenomena, surrounding this market, have already contributed to the commodization (the loss of value and the need to redefine the basic assumptions) of the certain types of services, and in relation to others, to their complete disappearance from the market. 
Megatrends in the environment of the postal industry decide that public operators face nowadays the necessity to change their operating models. Perhaps, in the near future, the need for a change will also apply to management paradigms.

The article addresses the subject of the postal industry from the perspective of management challenges, where one can notice a significant gap in Polish literature. The study has a theoretical character with practical aspects and is based on a review of scientific and popular science literature. The article updates the literature taking into account the current state of the postal industry`s affairs. Secondary data sources were used.

Keywords: development megatrends, CEP branch, logistics 4.0, commodization, postal operator.

Informacje o autorze:

dr Konrad Michalski

Szkoła Główna Gospodarstwa Wiejskiego w Warszawie

Wydział Nauk Ekonomicznych

Katedra Logistyki

ul. Nowoursynowska 166, 02-787 Warszawa

Tel.: (+48) 225935603

e-mail: konrad_michalski@sggw.pl

ORCID: 0000-0001-6997-352X 